Article

\title{
Foreign Venture Capital Firms in a Cross-Border Context: Empirical Insights from India
}

\author{
Kshitija Joshi ${ }^{1, *}$, Deepak Chandrashekar ${ }^{2}$, Alexander Brem ${ }^{3,4} \mathbb{1}$ and Kirankumar S. Momaya ${ }^{5}$ (D) \\ 1 School of Social Sciences, National Institute of Advanced Studies, Bengaluru 560012, India \\ 2 Xavier Institute of Management and Entrepreneurship, Bengaluru 560100, India; cdeepak73@gmail.com \\ 3 School of Business and Economics, Friedrich-Alexander-Universität Erlangen-Nürnberg (FAU), \\ 91054 Erlangen, Germany; alexander.brem@fau.de \\ 4 Technology Entrepreneurship and Innovation, University of Southern Denmark (SDU), Alsion 2, \\ 6400 Sønderborg, Denmark \\ 5 Shailesh J. Mehta School of Management, Indian Institute of Technology Bombay, Mumbai 400076, India; \\ momaya@iitb.ac.in \\ * Correspondence: kshitija74@gmail.com
}

Received: 8 October 2019; Accepted: 4 November 2019; Published: 8 November 2019

\begin{abstract}
Syndication or co-investment is a potent way of pooling resources among peer Venture Capital (VC) firms. This is even more vital for Foreign VC firms (FVCFs) when investing in destinations that are geographically distant from their countries of origin. Although FVCFs are relatively abundantly endowed in terms of financial capital, they are distinctly disadvantaged in terms of their social capital when investing in geographies that are distinctly different in terms of their institutions, norms, and culture from their own. One of the ways in which FVCFs overcome this impediment is by investing in human resources that serve as a bridge between their financial and social capital. Accordingly, the primary aim of this study is to investigate the relationship between the resources of FVCFs and their syndication intensity. Using the technique of logistic regression, we arrive at several interesting findings. FVCFs with a greater proportion of investment executives with prior founding experience in India and those with lower proportions of professionals of Indian origin demonstrate lower syndication intensity. Similarly, the syndication intensity diminishes with the increase in size of the investing team. FVCFs with greater fund size demonstrate a lower need for syndication. Greater endowment of social capital as proxied by the age of the VC firm is seen to enhance the syndication intensity.
\end{abstract}

Keywords: syndication; foreign VCs; VC sustainability; VC risk management; human capital; social capital

\section{Introduction}

As demonstrated by prior studies, Top Management Teams (TMTs) have been identified as the prime drivers of firms' strategies [1]. By virtue of their influence on firm-level processes and dynamics, they contribute significantly to firm performance, and the corresponding growth and expansion $[2,3]$. The human and social capital of these TMTs is considered an important source of competitive advantage for high-technology firms, positively impacting their sales growth and market returns [4]. Several studies in entrepreneurship and organizational literature have explored TMTs of large firms and small entrepreneurial start-ups [5]. In contrast, TMTs of venture capital firms (VCs) have received limited attention.

In this paper, we focus on the role of TMTs in impacting the syndication intensity of internationalizing VCs. Syndication refers to joint investment by two or more VCs in the same deal, while syndication 
intensity is defined as the overall proportion of syndicated deals in a VC firm's portfolio [6,7]. Risks from information asymmetry between the VCs and investee ventures are particularly pronounced for FVCFs given the variation across the geographies of their origin and investment destinations. Under these circumstances, their human capital (viz., the size and composition of their TMTs) is the most important attribute in overcoming such risks. The TMTs play an important role in determining if and to what extent their deals are syndicated. Although it is primarily the deal-related attributes that determine whether a specific deal is syndicated or not, it is the composition of organizational resources in general which influence the firm level syndication intensity. However, the existing evidence pertaining to the relative role of tangible financial versus other non-tangible resources (such as networks and expertise) in impacting the syndication intensity is relatively sketchy, with diverse studies coming up with contradictory results $[6,8]$.

Cross-border investments by western VCs often encounter severe information asymmetries due to geographic distance and cultural dissimilarities between the VC firms' countries of origin and the destination [9-11]. Limited know-how and inadequate local networks further compound these risks [12]. Conventionally, such risks have been handled by syndicating with other VCs in target markets, especially those with greater investment experience than themselves [7,13-15]. Any kind of syndication effort warrants the presence of strong social networks within the local VC-entrepreneurial ecosystem in target markets. Since their own connections are likely to be quite limited in investment destinations, the foreign VC firms (FVCFs) are known to piggy-back off the social capital of their investment executives (IEs). The latter help the syndication process accordingly, facilitating the access to local VC firms' business and legal know-how [16-19]. Since IE networks are vital for syndication, the size and composition of the IE team becomes an important aspect to examine for FVCFs. An understanding of the same may be critical to understanding the development of entrepreneurship, especially in emerging economies where FVCFs are increasingly seen to be playing a dominant role in nurturing entrepreneurial ventures. Therefore, the primary research question we address in this paper is: What is the role of the size and composition of FVCFs' investment teams in syndication intensity?

We examine this question for FVCFs investing in India. With about 80 percent of investible funds being raised overseas [20], 70 percent of active VC firms in India being of foreign origin, and 80 percent of funded deals being co-funded by FVCFs, they have emerged as the engine of growth of the Indian VC industry in recent years [21]. FVCFs are particularly important in India where, in addition to finance, they provide mentoring, international networks and access to overseas markets to local investees [22]. However, there is a dearth of studies on the syndication of FVCFs in India. Using the data on 37 active FVCFs and using the method of logistic regression, this study examines the role of human, social and financial capital in determining the syndication intensity of FVCFs. We find that prior founding experience of TMTs within the Indian set-up lowers syndication intensity. Larger size of the investing team also lowers syndication intensity. Higher fund sizes of the FVCFs lowers the need for syndication. Greater endowment of social capital enhances syndication intensity.

We make three contributions to the literature. First, we contribute to the literature on TMTs. Prior research has examined the size and composition of TMTs in various industries including bio-technology, high-tech, hospital set-ups, energy, and banking in both large and small firms. Although small in terms of their size, VCs are distinct because of their limited partnership structure, which has implications for the choice of their syndication partner unlike in large corporations where alliances may be driven by reasons of corporate diversification or growth in size by managers who are not necessarily owners. The performance of VC-funded investees is quite often contingent on the niche skillsets and networks of the specific TMT members who make investment decisions [23]. Therefore, factors like reputation and individual human and social capital of VC IEs become important with respect to whom and how they choose their co-investment partners. In our focus on the role of size and composition of VC IEs, we contribute to the TMT literature. In examining issues of ethnicity, we look beyond professional experience in impacting the alliance formation process in the TMT literature. Second, we contribute to the literature on VC syndication. The issue of syndication has been previously reviewed in a cross-border context $[10,12,19]$. Prior studies have focused on aspects 
such as choice of co-investment partner, portfolio choice and performance of investees funded by syndicates of VCs in foreign markets. However, in most studies, syndication is treated as a rather mechanical process that occurs in a vacuum and is devoid of human intervention. Although studies have examined the role of human capital of VC firms in impacting the development of entrepreneurship in developing countries [24], to the best of our knowledge, the link between size and composition of VC investment teams and syndication has not yet been adequately probed. Finally, in our focus on FVCFs in India, we extend the entrepreneurship literature on emerging economies. Prior studies have explored syndication strategies of FVCFs in China [12]. Although outwardly similar in many respects, India and China are strikingly different in terms of political systems, legal and financial institutional frameworks, innovation models, and overall attitudes towards free enterprise [25]; factors that may have implications for the strategies of FVCFs and their approach towards syndication in these economies. India is also different as compared to other economies, as despite the huge boom in VC here, it is still primarily being directed into later-stage ventures, while the nascent start-ups are starved of funds. Moreover, the risk-taking appetite of FVCFs is seen to be quite limited in the Indian context, as more tried and tested start-up models from the western world give them higher returns with minimum risks. Syndication can then be looked upon as one of the ways to overcome such risks.

The paper is structured as follows. In Section 2 we provide an overall context of FVCFs in India. This is followed by a review of the literature in Section 3. In Section 4, we derive propositions that outline the intensity of syndication based on human and financial resources of these FVCFs. Section 5 discusses the research methods. Section 6 presents the empirical results, while Section 7 provides a discussion of the same. Finally, Section 8 concludes with implications for theory and practice.

\section{Foreign VC in India}

Ranking fourth in the world, India has emerged among the most favored destinations for the deployment of global VC funds in recent years [20]. FVCFs have led the rally of growth of VC investments in India. In 2014, about 54 percent of FDI received by India was in the form of VC or Private Equity [26]. Eighty percent of VC funds invested in India are raised overseas [20,22,27,28]. Several FVCFs have raised large India-focused funds with the sole target of investing in India [29]. Several MNCs (such as Intel, Qualcomm, SAP and Cisco) have established corporate VC arms to leverage the technologies developed by the Indian start-ups [21,29]. Other global technology giants such as Microsoft, Google and Amazon have set up their own business accelerators.

Despite their growing influence, FVCFs investing in India encounter remarkable challenges. To start with, India ranks 77 out of 158 on the Ease of Doing Business Index developed by the World Bank Group [30] and 85 out of 175 on the Public-Sector Corruption Index [31]. A recent study on VC investing in India revealed the existence of a severe trust deficit between VCs and entrepreneurs [32], especially in early-stage ventures. As legal processes are yet to catch up with the rapidly evolving VC-entrepreneur ecosystem in India, it can be difficult to enforce contracts [33]. Indian entrepreneurs still regard VC largely as a funding source, and resist VC involvement in operational and strategic areas of their ventures [22]. Furthermore, winding up a business in India is a complex and time-consuming process [21].

Collectively, these factors considerably enhance investment risks for FVCFs in India. Thus, it is almost imperative for FVCFs to form suitable alliances with other VC firms that are relatively better connected within the local ecosystem. Since such alliances cannot be formed automatically, but only by means of conscious efforts of the IEs, it is important to probe the effect of the team size and composition of the IE in impacting syndication.

\section{Literature Review}

This section presents a review of the literature pertaining to TMTs and VC syndication. 


\subsection{Top Management Teams—Size and Composition}

Although the overall human capital composition of any firm is critical in influencing organizational strategies and outcomes, most critical decisions are inevitably drawn by their TMTs [3]. Literature pertaining to TMTs has largely been based on the Upper Echelon (UE) theory, which envisages the perceptions and cognition abilities of TMTs as prime determinants of firm-level strategies and performance [1].

In the cross-border context, the size and composition of TMTs are known to play an important role in influencing the most vital firm-level strategies. Previous experience of members of TMT (in terms of number of previous employers, seniority in rank and prior international exposure) is found to enhance the formation of alliances, international involvement, and globalization [34,35]. Moreover, specific educational qualifications have been associated with greater international diversification $[2,36]$. Apart from individual attributes, the overall diversity and heterogeneity of TMTs (in terms of age, gender, race, etc.), and its impact on various firm level strategic aspects has also been examined [37]. In general, diverse teams are found to be associated with better organizational outcomes. Additionally, the social networks of TMT members have been regarded quite vital and a greater range and strength of networks has been found to have a positive impact on sales growth and stock market returns [4].

Compared to other organization types, the TMTs of VCs have been analyzed to a very limited extent. Although the TMTs of the VC-funded investee firms [38] have been examined in much detail, those of the VCs themselves have been reviewed only sparingly. For the few studies that exist, the emphasis has largely been on assessing the impact of TMT composition on either portfolio choice viz. investment-stage and technology focus [23,39,40] or investee firm or VC fund performance [41,42], but rarely on the syndication process.

In the cross-border context, Madhavan and Iriyama [43] probed the role of human capital networks as primary 'carriers' for cross-border VC flows. In China, although the vital role played by the TMTs has been duly acknowledged, the specific micro-aspects of TMT composition and the precise role of these TMT executives at the investments destinations has not yet been probed [44].

\subsection{VC Syndication-Human and Social Capital}

The existent VC literature has identified several motives for syndication, with 'resource-based' motivation being the most prominent among these. As per the resource-based view (RBV), firms comprise a historically determined collection of resources that are valuable, rare, imperfectly imitable, non-substitutable, and semi-permanently tied to their management [45,46]. Such resources, fundamental to the firm's competitive advantage can take both tangible (physical or financial resources) and non-tangible forms (such as organizational routines, capabilities and the information and knowledge). Thus, per RBV, syndication arises from the need for risk reduction via pooling of tangible and non-tangible resources, culminating in better selection and management of investments [15,47-49] ultimately resulting in an enhanced venture valuation [50].

Therefore, in general, the core motivation for syndication seems to emanate from the need to leverage 'external' social capital $[15,51]$. Social capital refers to the relational and structural resources attained by leveraging the network of social relationships [52]. This includes both formal and informal alliances with firms, individuals, and organizations, which opens access to new information, technology, and markets [53,54]. Social capital facilitates access to financial capital as well and is also found to enhance the level of intellectual capital [55].

In the VC industry, where information on deals is rarely public, social capital in the form of inter-firm relationships (as represented by syndication) is likely to play a crucial role in granting access to better-quality deals [51]. For cross-border investments, syndication mainly serves the purpose of compensating for FVCFs' limited local networks. The social capital of FVCFs is mainly in the form of their international business networks [17], while investments in nascent ventures warrant a deep understanding of specific local conditions $[19,56]$. This gap is effectively filled by joint syndicates of domestic VCs and FVCFs. The resource complementarity derived from the combination of 'localness' 
and 'foreignness' resulting from local know-how and networks and exposure to international markets enables FVCFs to invest in deals with greater information asymmetry $[10,57]$ and has also been linked to superior venture performance [19].

While such alliances among VC firms are almost imperative, it is also important to understand the alliance formation process. In fact, alliances are seldom formed automatically; rather, they ensue from the conscious efforts of VC TMTs from leveraging their pre-existing personal and professional relationships. Thus, the human capital of the VC firms plays a vital role in the enhancement of their social capital [58] and hence needs to be viewed as a prime driver of syndication intensity. It is in this regard that an analysis of human capital of the VC TMTs becomes important. In case of other entrepreneurial firms, the human capital has been found to play a strategic role in opportunity recognition and exploitation [58] and innovation [59], thus enhancing the likelihood of firm survival, growth, wealth creation and profitability [60]. The same is likely to hold in the context of VCs as well.

Previous studies in the context of human capital of VC firms have reviewed its composition and analyzed its influence on the firm strategies and performance. Accordingly, the educational and work histories of VC TMTs have been intensely probed and correlated with their portfolio focus (stage and technology focus of investee ventures), fund performance and internationalization [23,40,42]. The impact of 'general' and 'task-specific' human capital on the relative perceptions of risk, return, opportunities and threats and its ensuing effect on un/successful exits have also been probed [41].

In general, the prior entrepreneurial experience of the VC team members is found to enhance their opportunity recognition potential, and thus, such VCs are seen to fund early stage deals which in turn is associated with a better fund performance [23,42]. Other studies have probed how the specific educational and work backgrounds of $\mathrm{VC}$ team members result in cognitive biases that impact the criteria deployed by them at the deal selection phase $[39,61]$. Furthermore, the role of size and composition of the TMTs as an influencer of the syndication intensity has also been assessed. In general, a larger TMT size implies a wider range of contacts and thus is found to enhance the syndication intensity [7]. While this points to the significant role played by human networks and the social capital in syndication, there exists no conclusive evidence about how the specific skillsets or socio-cultural attributes of the team impacts the same. To this end, Jungwirth and Moog [7] find no significant difference in the syndication intensity of the 'specialist' and 'generalist' VCs where these terms have been defined based on the past education and experience of the respective team members.

\subsection{Research Gaps}

A review of the literature reveals that, while the syndication strategies and human capital of VC firms have been separately analyzed so far, there have been only limited attempts to explicitly probe the link between the two.

As such, the literature pertaining to TMTs of VCs is quite limited. Even where it exists, the focus has been on attributes such as education and professional experience [23,42], while other important traits such as ethnicity of the VC IEs have been overlooked. In the cross-border context, the TMTs of VCs have not been analyzed at all.

Secondly, although the issue of syndication has been probed intensely within local contexts [62] and sparingly in the cross-border contexts [12,63], the explicit role of human capital of VCs in impacting the process of alliance formation in the form of syndication has been investigated adequately.

Finally, despite the rapid emergence of India among the prime international VC investment destinations [20], the strategies of these FVCFs in India are not yet adequately understood. In the face of increasing internationalization of the VC industry, we believe that it is important to probe these issues.

\section{Theory and Propositions}

In this section, we use RBV to develop exploratory propositions regarding the impact of human resource composition and financial resources on the syndication intensity of the FVCFs in India. 


\subsection{Role of Human Capital in Syndication by FVCFs in India}

The composition of human capital is a vital resource for any VC firm. Unlike conventional financial intermediaries, which mainly provide financial capital, VC IEs also provide social capital in the form of access to networks, expertise and advice to investees [15,64]. In India, where a severe trust deficit is known to exist among VCs and entrepreneurs [32], social capital in the form of the personalized connections of VC IEs is likely be particularly imperative.

For this paper, we focus on four attributes concerning the VC TMT—ethnicity, prior founding experience, prior VC investing experience, and team size.

\subsubsection{Ethnicity}

Evidence from China suggests that while investing in geographically distant destinations, FVCFs consciously hire local professionals to manage their regional offices [12,44]. The impact of homophily resulting from similar experiences, organizational structures and goals has already been found to aid VC syndication [12,51]. Moreover, among the various known forms of homophily, the tendency to form ties based on ethnic/racial background has been acknowledged to be the strongest [65].

In the context of other firms, the 'bridging social capital' or 'weak ties' of the managers have been found to serve as conduits of information about innovation, the availability and character of markets, products, and resources [58]. In the context of FVCFs, as well, the homophily resulting from nationality and ethnicity is likely to be pertinent in the formation of ties among VC IEs and the resultant social capital crucial in impacting the syndication intensity. Hence, we advance our first proposition:

Proposition 1. The presence of a greater proportion of professionals of Indian origin as IEs is likely to enhance the syndication intensity.

\subsubsection{Prior Founding Experience}

Prior founding experience of IEs has been found to enrich their perceptions of underlying risks, enhance their knowledge of market entry, and augment their potential for identifying agency problems [42]. Furthermore, such experience is likely to enable them to better assist the venture during the post-investment period $[38,66]$. Moreover, such IEs are known to better identify with the investee ventures and be supportive of them [42].

Also, previous VC research demonstrates that geographic and social proximity to investees plays a primal role in the formation of social ties [51]. Given that the prior founding experience is in the same geography as the investment destination, these IEs are also likely to be better-networked within the local ecosystem. To that extent, the reliance on other VC firms for access to social capital is lower. Thus, we believe that the IEs with prior founding experience (in India) are likely to syndicate less intensely.

Proposition 2. Presence of IEs possessing prior founding experience in India is likely to lower the syndication intensity.

\subsubsection{Prior VC Investing Experience}

The role of social capital in accessing high-quality deals [51] — hence impacting VC firm strategy—is well understood [67]. Prior experience in the VC industry is likely to significantly enhance the contacts with the VC-entrepreneurial ecosystem and accordingly augment the level of social capital. In fact, these 'generalist' VCs (i.e., VCs with basic know-how in financing new enterprises) are known to trade their 'access to deal flow' for 'access to knowledge' by co-investing with 'specialist' VCs (those with specialized industry or founding experience), which in turn is reflected in their higher intensity of syndication [7]. In fact, in India, since the very inception, FVCFs are known to have consciously pursued a strategy of hiring their IEs from their domestic counterparts with the aim of piggy-backing 
on the latter's social networks [68]. Their pre-existing social capital is likely to facilitate the syndication process and is thus positively impact the overall syndication intensity.

At the same time, prior work experience in the VC industry is likely to make IEs adept in selecting and supporting their investees [23,69-71]. Such skillsets in themselves constitute a niche resource, which reduces their need to syndicate, and accordingly is likely to lower their intensity of syndication. Based on the above, we frame two contrasting propositions:

Proposition 3a. Prior VC investing experience of the IEs is likely to enhance the syndication intensity.

Proposition 3b. Prior VC investing experience of the IEs is likely to lower the syndication intensity.

\subsubsection{Size of Investment Team}

Team size has been identified as an important determinant of firm strategy (related to diversification or internationalization) and performance [35,72,73]. In general, larger teams imply more resources, a greater range of analytical skills [15], and a greater spread of social capital. Thus, larger investment teams are likely to reduce the need for additional complementary resources and are thus less likely to syndicate intensely.

However, VCs with larger teams are likely to get approached more often by potential partners seeking co-investment and are thus likely to syndicate more intensely [7]. Likewise, larger team sizes may be associated with greater conflicts and delays in decision-making [74], consequently negatively impacting the syndication intensity.

Based on this, we advance the following propositions:

Proposition 4a. Larger size of the IE team is likely to lower the syndication intensity.

Proposition $\mathbf{4 b}$. Larger size of the IE team is likely to enhance the syndication intensity.

\subsection{Role of Financial Capital in Syndication by FVCFs in India}

The sharing of financial resources is another important motive for syndication. Syndication compensates for the lack of financial resources, thus offering a means to support larger deal sizes than feasible otherwise [50].

In India, where the domestic funding sources are likely to be severely restricted (owing to the regulatory restrictions on provident and pension funds and insurance companies contributing to the VC fund corpus) [21] and where the need for investment funds across the spectrum is ever-increasing due to the large scale of the market, the corpus of VC firm-level financial resources is critical in determining its syndication intensity.

Based on this, we advance the following proposition:

Proposition 5. Larger fund sizes are likely to lower the syndication intensity.

\section{Data and Methodology}

\subsection{Scope, Data and Methods of Analysis}

This study is based on secondary data obtained from Venture Intelligence (VI), a private database for VC and PE deals in India. The unit of analysis for the study is an individual FVCF. For this analysis, we selected all those FVCFs that had funded at least 2 deals (37 FVCFs in all) over the period of study, viz., 2005-2013. The 37 FVCFs in our sample constituted about 30 percent of all FVCFs registered in the 
VI database, and contributed to more than 90 percent of the overall VC deals funded by FVCFs during the period of study.

Data were analyzed in two steps. A preliminary analysis (descriptive statistics and Pearson bi-variate correlations) was first conducted. This was followed by logistic regression models to discern the relationships between the key variables. The analysis was performed using SPSS 21.0.0.0 software. In the former, we report the mean, standard deviations, minimum/maximum values, and Pearson bi-variate correlations. For the logistic regression models, we report the model coefficients and their significance levels, Nagelkerke $\mathrm{R}^{2}$, overall model Chi-squared value, Hosmer-Lemeshow statistic, and the percentage of pairs correctly classified.

\subsection{Variables}

\subsubsection{Dependent Variable: Intensity of Syndication}

We created the variable proportion of syndicated deals for each FVCF in our sample. This was done by calculating the ratio of the total number of syndicated deals to the total number of deals funded by each firm. Next, we created a dichotomous variable, intensity of syndication, by comparing the overall proportion of syndicated deals across all FVCFs in our sample with that for each FVCF separately. Here, we found that overall the FVCFs syndicated 58 percent of their deals, on average. FVCFs that exhibited an incidence of syndicated deals above the overall average ( $>=58$ per cent), were deemed to be 'high' syndicators and were categorized as 1 , while those below the overall average ( $<58$ percent) were deemed to be 'low' syndicators and categorized as 0 . The binary variable thus created was then used as the dependent variable in our models.

\subsubsection{Independent Variables}

Human Resource-related variables:

The demographics of the FVCF TMTs were obtained from the respective VC firm websites. Along the lines of Dimov and Shepherd [41] and Patzelt et al. [42], we visited the sections entailed 'management' or 'investment team' on websites, where the CVs of the team members are described. Following Patzelt et al. [42], the VC firm professionals with the highest-ranking titles (such as General Partner, Partner, Principal, Managing Director, President, Vice-President) were deemed to comprise their IEs.

We created six different variables to assess the demographic profile of the IEs: Ethnicity (proportion of Indian origin professionals), Prior founding experience (in India), Prior founding experience overseas, Prior technology entrepreneurs, Prior experience with other VC firms (in India and overseas) and Size of investment team. Of these, the Ethnicity and the Size of investment team are continuous variables, whereas the rest are dummy variables. In the case of the latter, even if a single IE of the VC firm was found to possess the relevant professional background (founding or investing experience), the variable was categorized to take the value 1 , else 0 .

Ethnicity: Based on their last names, the IEs were identified as those belonging to Indian origin. The proportion of executives having Indian origin was then computed for each VC firm.

Prior founding experience (in India): Dummy variable to determine if any of the IEs had established a business venture in India in the past.

Prior founding experience overseas: Dummy variable to determine if any of the IEs had established a business venture overseas in the past.

Prior technology entrepreneurs: Dummy variable to determine if any of the IEs had established a business in high-technology domains in the past (in India or overseas).

Prior experience in other VC firms (in India and overseas): Dummy variable to determine if any of the IEs had worked for other VC/PE firms (in India or overseas)

Size of investment team: Number of IEs in each FVCF

Fund size (Financial Capital) of the VC Firm: 
The data pertaining to fund size of each of these firms were obtained from VI and other private websites that track the ongoing activities of the VC firms operating in India (VCCircle.com, Crunchbase.com, Yourstory.com).

The financial resources of the VC firm are represented by their respective fund-sizes in USD million

\subsubsection{Control Variables}

We chose Age of the VC firm, Number and Value of historical investments, Geography (dummy variable for whether the FVCF is in Bangalore), Early Stage Focus, High-Tech Domain Focus, and Foreign Entry mode (dummy variable to indicate the presence of a physical office in India) as control variables.

Age and historical investments are likely to influence the level of social capital of the FVCF [12] and hence need to be controlled for.

Moreover, the VC firms located in entrepreneurial hubs are likely to pursue different investment strategies as compared to others [75]. Bangalore is considered to be among the prominent global technology hubs and is known to possess one of the most vibrant VC-start-up ecosystems in India [76,77]; this is likely to influence firm strategy. Thus, we created the indicator variable Geography to account for the fact that the VC firm is in Bangalore.

Moreover, it is well-understood that early-stage-focused and high-tech-focused VC firms are known to syndicate intensely to overcome the information asymmetries [62]. Thus, we used these as additional control variables. Early-Stage Focus was defined as the proportion of early stage deals, whereas High-Tech Domain Focus was defined as the proportion of deals belonging to IT and ITeS domains in the FVCF portfolios.

The presence of a physical office at the destination of investment is understood to significantly affect the choice of syndication partners [12]. We conjecture that it might impact the syndication intensity as well, and hence include it as another control variable.

\subsection{Data Analysis}

Table 1 provides a description of the key variables along with their data sources.

Table 1. Variable definitions and data sources.

\begin{tabular}{ccc}
\hline Variable Name & Abbreviation & Data Source \\
\hline Proportion Syndicated Deals & Syndicated & Venture Intelligence \\
‘High' Syndication (Above average Syndication) & High-Synd & Created \\
Proportion Early Stage & Early Stage Focus & Venture Intelligence \\
Proportion High-Tech & High-Tech Focus & Venture Intelligence \\
VC Firm Age & Age & Venture Intelligence \\
Aggregate Investments (2005-2013) in USD Mn & Investments & Venture Intelligence \\
Historically Funded Deals (2005-2013) & Deals & Venture Intelligence \\
Presence of Physical Office in India & India Office & Venture Intelligence \\
Founding Experience in India & India Founders & Compiled from VC Firm websites \\
Founding Experience Overseas & Overseas Founders & Compiled from VC Firm websites \\
Erstwhile Technology Entrepreneurs & Tech Entrepreneurs & Compiled from VC Firm websites \\
Erstwhile VC investing Experience & VC Investors & Compiled from VC Firm websites \\
Team Size India & Team Size & Compiled from VC Firm websites \\
Proportion India Origin Professionals & India Origin & Compiled from VC Firm websites \\
Fund Size in USD Mn & Fund size & Compiled from VCCircle.com, \\
Location Bangalore & Crunchbase.com, Yourstory.com \\
\hline
\end{tabular}




\subsubsection{Preliminary Data Analysis}

The descriptive statistics presented in Table 2.

Table 2. Descriptive Statistics.

\begin{tabular}{cccccc}
\hline Variables & $\mathbf{N}$ & Mean & Std. Deviation & Minimum & Maximum \\
\hline Syndicated & 37 & 0.58 & 0.27 & 0 & 1 \\
High-Synd & 37 & 0.54 & 0.51 & 0 & 1 \\
Early Stage Focus & 37 & 0.61 & 0.23 & 0 & 1 \\
High-Tech Focus & 37 & 0.71 & 0.30 & 0 & 1 \\
Age & 37 & 8.00 & 2.01 & 2 & 14 \\
Investments & 37 & 137.69 & 147.86 & 0 & 750 \\
Deals & 37 & 22.32 & 24.93 & 2 & 110 \\
India Office & 37 & 0.73 & 0.450 & 0 & 1 \\
India Founders & 37 & 0.16 & 0.37 & 0 & 1 \\
Overseas Founders & 37 & 0.32 & 0.47 & 0 & 1 \\
Tech Entrepreneurs & 37 & 0.46 & 0.51 & 0 & 1 \\
VC Investors & 37 & 0.65 & 0.48 & 0 & 1 \\
Team Size & 37 & 6.27 & 5.27 & 1 & 28 \\
India Origin & 37 & 0.79 & 0.30 & 0.11 & 1 \\
Fund size & 37 & 328.64 & 295.47 & 0.21 & 1200 \\
Bangalore & 37 & 0.30 & 0.46 & 0 & 1 \\
\hline
\end{tabular}

On average, the overall proportion of syndicated deals across all FVCFs is about 58 per cent. Based on this, about 54 percent of the FVCFs in our sample have a proportion of syndicated deals higher than the average and 46 percent have lower than average proportion of syndicated deals.

16 percent of the FVCFs employ IEs with prior founding experience in India, about 32 percent have founded firms overseas, and about 46 percent of them have set up entrepreneurial ventures in technology domains. About 65 percent of the VC firms have IEs with the experience of having worked with other VC firms in the past (in India or overseas). The average IE team size is about 6 members, and on an average 79 percent of the IEs are of Indian origin.

On average, about 61 percent of the deals exhibit an early-stage focus, while 71 percent of the deals are focused on 'high-tech' domains. The average age of FVCFs in our sample is about eight years, with each of them having funded about 22 deals over the period 2005-2013, and having made average investments worth USD 137 million. About 73 percent of the FVCFs in our sample had established a physical office in India, while others operated remotely from their home countries. The average fund size is about USD 328 million, and about 30 percent of the sample firms are located in Bangalore.

\subsubsection{Creation of Additional Variables}

Pearson bi-variate correlations among the variables are presented in Table 3.

In addition to the correlations that appear significant there, our initial data analysis also revealed that the dependent variable exhibited strong non-linear relationships with other independent variables. Such non-linear relationships can either be modeled using variable transformations or creating appropriate dummy variables to capture the non-linearities [78]. We chose to follow the latter approach since it yielded sharper results. Accordingly, five other derived variables were created and the details for the same are given in Table 4. These variables were created by plotting the relationship between the dependent variable and the original raw variable and creating dummy variables to capture the non-linearities observed therein. From Table 4, it may be seen that the correlations of the newly created variables with the dependent variable are higher than the variables in their original form. 
Table 3. Bi-variate correlations.

\begin{tabular}{|c|c|c|c|c|c|c|c|c|c|c|c|c|c|c|c|c|}
\hline & 1 & $2(\mathrm{DV})$ & 3 & 4 & 5 & 6 & 7 & 8 & 9 & 10 & 11 & 12 & 13 & 14 & 15 & 16 \\
\hline 1 & 1 & $.793^{* *}$ & -.079 & .291 & .150 & .132 & .103 & -.239 & -.208 & .063 & -.057 & .011 & -.275 & .132 & -.165 & .209 \\
\hline 2 & $.793^{* *}$ & 1 & .024 & $.359^{*}$ & -.055 & -.018 & .056 & -.195 & $-.330^{*}$ & .059 & -.129 & .003 & $-.369^{*}$ & .124 & -.242 & .244 \\
\hline 3 & -.079 & .024 & 1 & $.400^{*}$ & -.271 & .059 & .193 & -.322 & .289 & $.338^{*}$ & $.440^{* *}$ & -.252 & -.069 & .133 & -.190 & .154 \\
\hline 4 & .291 & $.359^{*}$ & $.400^{*}$ & 1 & -.072 & -.017 & .010 & $-.327^{*}$ & .078 & .250 & .240 & -.215 & -.230 & $.347^{*}$ & -.283 & .246 \\
\hline 5 & .150 & -.055 & -.271 & -.072 & 1 & $.533^{* *}$ & $.409^{*}$ & $.337^{*}$ & .000 & $-.378^{*}$ & -.191 & $.371^{*}$ & $.411^{*}$ & .079 & $.404^{*}$ & .149 \\
\hline 6 & .132 & -.018 & .059 & -.017 & $.533^{* *}$ & 1 & $.922^{* *}$ & .259 & $.419^{* *}$ & -.215 & .158 & .262 & $.352^{*}$ & .224 & $.467^{* *}$ & .274 \\
\hline 7 & .103 & .056 & .193 & .010 & $.409^{*}$ & $.922^{* *}$ & 1 & .280 & $.367^{*}$ & -.087 & .228 & .254 & $.333^{*}$ & .258 & $.427^{* *}$ & $.374^{*}$ \\
\hline 8 & -.239 & -.195 & -.322 & $-.327^{*}$ & $.337^{*}$ & .259 & .280 & 1 & .103 & -.228 & -.050 & $.444^{* *}$ & .312 & .288 & .257 & $.396^{*}$ \\
\hline 9 & -.208 & $-.330^{*}$ & .289 & .078 & .000 & $.419^{* *}$ & $.367^{*}$ & .103 & 1 & -.148 & $.477^{* *}$ & .170 & $.485^{* *}$ & .213 & .086 & .035 \\
\hline 10 & .063 & .059 & $.338^{*}$ & .250 & $-.378^{*}$ & -.215 & -.087 & -.228 & -.148 & 1 & $.751^{* *}$ & $-.699^{* *}$ & -.225 & .044 & $-.429^{* *}$ & .055 \\
\hline 11 & -.057 & -.129 & $.440^{* *}$ & .240 & -.191 & .158 & .228 & -.050 & $.477^{* *}$ & $.751^{* *}$ & 1 & $-.457^{* *}$ & .171 & .206 & -.281 & .112 \\
\hline 12 & .011 & .003 & -.252 & -.215 & $.371^{*}$ & .262 & .254 & $.444^{* *}$ & .170 & $-.699^{* *}$ & $-.457^{* *}$ & 1 & $.354^{*}$ & .075 & $.381^{*}$ & .107 \\
\hline 13 & -.275 & $-.369^{*}$ & -.069 & -.230 & $.411^{*}$ & $.352^{*}$ & $.333^{*}$ & .312 & $.485^{* *}$ & -.225 & .171 & $.354^{*}$ & 1 & -.027 & .290 & -.091 \\
\hline 14 & .132 & .124 & .133 & $.347^{*}$ & .079 & .224 & .258 & .288 & .213 & .044 & .206 & .075 & -.027 & 1 & .089 & .310 \\
\hline 15 & -.165 & -.242 & -.190 & -.283 & $.404^{*}$ & $.467^{* *}$ & $.427^{* *}$ & .257 & .086 & $-.429^{* *}$ & -.281 & $.381^{*}$ & .290 & .089 & 1 & -.111 \\
\hline 16 & .209 & .244 & .154 & .246 & .149 & .274 & $.374^{*}$ & $.396^{*}$ & .035 & .055 & .112 & .107 & -.091 & .310 & -.111 & 1 \\
\hline
\end{tabular}

Note: Levels of significance ${ }^{* *}<0.05,{ }^{*}<0.1$. Legend: 1. Syndicated, 2. High-Synd (DV - Dependent Variable),3. Early Stage Focus, 4. High-Tech Focus, 5.VC Age, 6. Investments, 7. Deals, 8. India Office, 9. India Founders, 10. Overseas Founders, 11. Tech Entrepreneurs, 12. VC Investors, 13. Team Size, 14. India Origin, 15. Fund size, 16. Bangalore. Note: Column 3 (corresponding to variable 2) presents the correlations for each of the independent variables with respect to the dependent variable. 
Table 4. Rationale and method of creation of new variables from original raw variables.

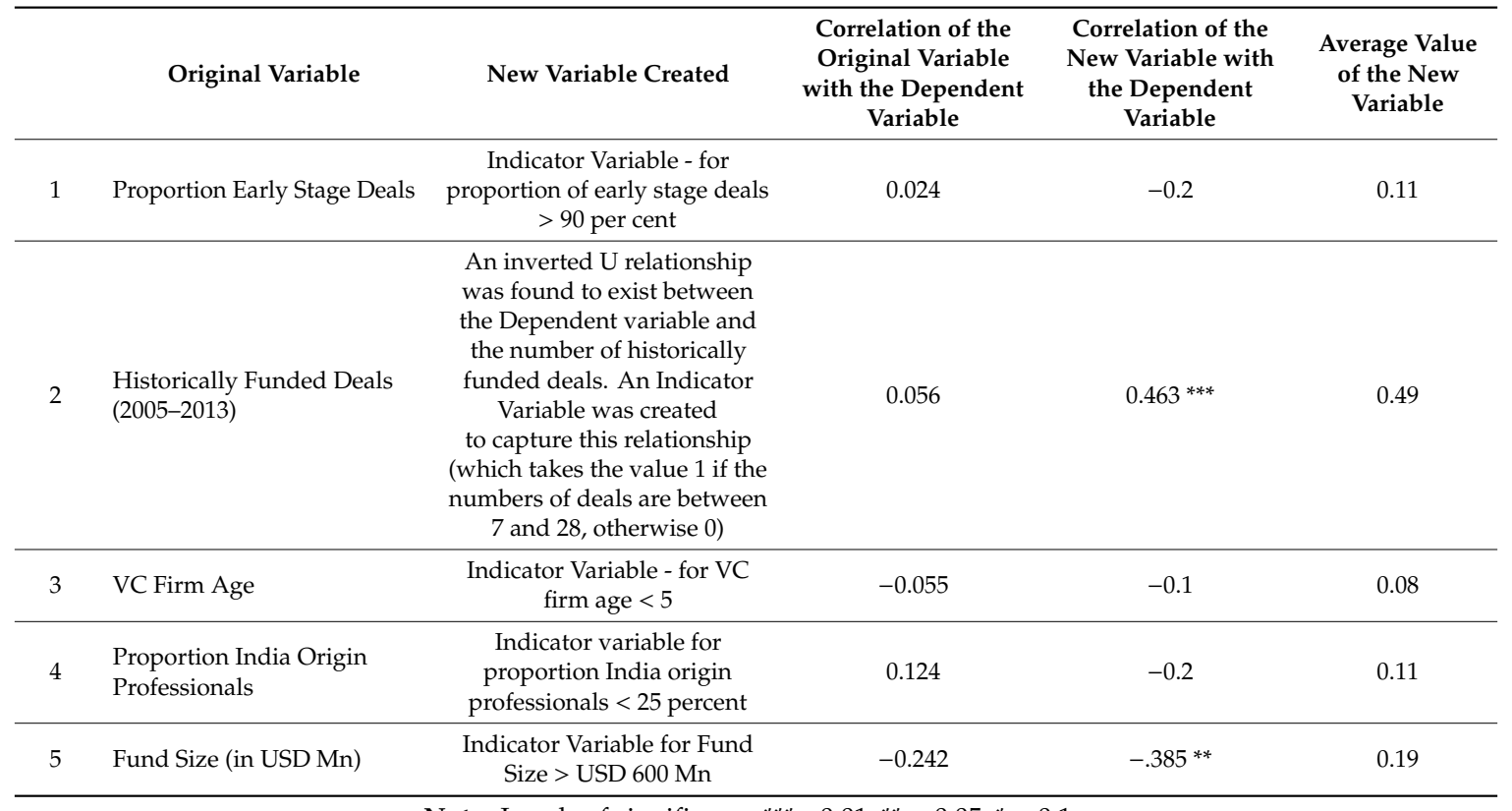

Note: Levels of significance ${ }^{* *}<0.01,{ }^{* *}<0.05,{ }^{*}<0.1$.

From the average values for the created variables, it can be seen that about 11 percent of the FVCFs in our sample had greater than 90 percent of their deals having an early stage focus, and about 49 percent of them had funded about 7 to 28 deals previously, about 8 percent of them had a number of years of operations in India of less than 5 years, about 11 percent of the VC firms had IE teams consisting of less than 25 percent professionals of Indian origin, and about 19 percent of them had raised funds in excess of $\$ 600$ million.

Along with the regression model statistics presented in Table 5, we also tested for multicollinearity by computing tolerance values, variance inflation factors, condition indices, and variance proportions. Based on the threshold values of the same as specified in Hair et al. [79], we conclude that multicollinearity is not a problem in our dataset. Since not all variables could be accommodated in the same model owing to the ensuing lower significance levels and the underlying Degrees of Freedom issues, we built 5 separate models to assess the impact of all variables.

Table 5. Regression results (for propensity towards high syndication).

\begin{tabular}{|c|c|c|c|c|c|}
\hline \multicolumn{6}{|c|}{$\begin{array}{c}\text { Dependent Variable-High Syndicators: Takes value of } 1 \text { if the overall proportion of Syndicated } \\
\text { Deals is }>58 \% \text {, and } 0 \text { otherwise }\end{array}$} \\
\hline & Model1 & Model2 & Model3 & Model4 & Model5 \\
\hline Constant & -1.854 & 0.886 & 0.702 & 1.077 & $2.432 *$ \\
\hline \multicolumn{6}{|l|}{ Human Resources Related Variables } \\
\hline $\begin{array}{c}\text { India-Origin } \\
\text { (Indicator variable for Proportion of India-origin } \\
\text { Professionals }<25 \% \text { ) }\end{array}$ & & & $-2.712 * *$ & & \\
\hline Team Size India & & & & $-0.207 * *$ & \\
\hline India Founders & & & $-2.761 * *$ & & \\
\hline VC Investors & & & 1.134 & & \\
\hline \multicolumn{6}{|l|}{ Financial Resources Related Variables } \\
\hline $\begin{array}{c}\text { Fund Size } \\
\text { (Indicator Variable for Fund Size > USD } 600 \mathrm{Mn} \text { ) }\end{array}$ & $-2.370 *$ & $-0.349^{* *}$ & $-3.099 * *$ & & -2.493 * \\
\hline
\end{tabular}


Table 5. Cont.

\begin{tabular}{|c|c|c|c|c|c|}
\hline \multicolumn{6}{|c|}{$\begin{array}{c}\text { Dependent Variable-High Syndicators: Takes value of } 1 \text { if the overall proportion of Syndicated } \\
\text { Deals is }>58 \% \text {, and } 0 \text { otherwise }\end{array}$} \\
\hline & Model1 & Model2 & Model3 & Model4 & Model5 \\
\hline \multicolumn{6}{|l|}{ Control Variables } \\
\hline $\begin{array}{c}\text { Deals } \\
\text { (Indicator Variable for } 7 \text { to } 28 \text { Historically } \\
\text { Funded Deals) }\end{array}$ & & $3.297 * * *$ & & & \\
\hline Investments & & $0.008^{*}$ & & & \\
\hline $\begin{array}{c}\text { VC Age } \\
\text { (Indicator Variable for VC Age }<5 \text { ) }\end{array}$ & & -0.344 & & & $-3.125 *$ \\
\hline India Office & & & & & $-2.722 * *$ \\
\hline $\begin{array}{c}\text { Early Stage Focus } \\
\text { (Indicator Variable - Proportion Early Stage } \\
\text { Deals }>90 \% \text { ) }\end{array}$ & $-3.315^{* *}$ & & & & \\
\hline High-Tech & $3.441 * *$ & & & & \\
\hline \multirow[t]{2}{*}{ Bangalore } & 1.105 & & & 1.168 & $1.541 *$ \\
\hline & \multicolumn{5}{|c|}{ Model Statistics } \\
\hline Number of Observations & 37 & 37 & 37 & 37 & 37 \\
\hline Model Chi-Square & $16.118^{* * *}$ & $19.014^{* * *}$ & $14.942 * * *$ & $8.037^{* *}$ & $13.572 * * *$ \\
\hline Pseudo R-Square (Nagelkerke R-Square) & 0.472 & 0.537 & 0.444 & 0.261 & 0.41 \\
\hline$\%$ Correctly Classified & $78.40 \%$ & $75.70 \%$ & $78.40 \%$ & $73.00 \%$ & $73.00 \%$ \\
\hline
\end{tabular}

\section{Results}

Table 5 presents the results obtained from logistic regression, which strongly support the resource-based motivations for syndication.

Among the human capital-related variables, we found support for Proposition 1, implying that native Ethnicity is likely to be associated with a greater syndication intensity. In this regard, we found that the VC firms with a relatively lower proportion of India-origin professionals (i.e., $<25 \%$ ) were less likely to syndicate intensely. Conversely, the greater the proportion of professionals of Indian origin, the higher the syndication intensity was.

Next, we also found support for Proposition 2, viz., VC firms with IEs having prior founding experience in India were less likely to syndicate intensely. Propositions $3 a$ and $3 b$ could not be established-i.e., previous experience on the part of the IEs in terms of working for other VC firms did not significantly impact the intensity of syndication. Next, we also found support for Proposition $4 a$-larger IE team size of FVCFs was found to be positively associated with syndication intensity.

Lastly, we also found support for Proposition 5. Here, we found that the VC firms with larger fund sizes (> \$ 600 million) were less prone to syndicate.

Among the control variables, we found that historically funded deals (both their number and value) and age of the FVCFs were important in influencing their syndication intensity. However, there existed significant variations with respect to the relationship between the syndication intensity and each of these variables. To start with, we found an inverted U-shaped relationship between the proportion of historically funded deals and the syndication intensity. Accordingly, the VC firms with a moderate range of funded deals (7 to 28 deals) were found to syndicate most intensely (and those with either very low or very high numbers of funded deals were found to syndicate less intensely). Further VCs with a greater magnitude of historical investments (in USD Mn) were found to syndicate more intensely. Moreover, younger VC firms (age $<5$ years) were found to syndicate less intensely. 
Furthermore, we found the presence of a physical office in India to be negatively associated with the intensity of syndication. Also, the FVCFs located in Bangalore were likely to syndicate more intensely. Among the investment-stage and technology-focus related variables, we found that FVCFs with greater exposure to high-tech deals were likely to exhibit higher syndication intensity. On the contrary, it was surprising to find that a higher incidence of early stage deals in the FVCF portfolio (>90\% early stage deals) negatively impacted its syndication intensity.

\section{Discussion}

In this exploratory paper, we provide a detailed analysis about the syndication intensity of the FVCFs in India. Using the resource-based theory, we obtain insights about how the human, financial, and social capital of FVCFs impact their syndication intensity. Furthermore, we also assess how their age and experience, portfolio choices (funding stage and high-technology focus), and the mode of foreign market entry impact their syndication intensity.

Our results are summarized as follows. To start with, we find that the human capital of the FVCFs, i.e., the composition of their IEs, is a vital determinant of their syndication intensity. Our results highlight the significance of both the quantum of expertise (team size) and the specific skillsets of the VC IEs. Accordingly, we find that larger team size is associated with a lower intensity of syndication.

Similarly, we find that the IEs with prior founding experience in India, demonstrate a lower intensity of syndication. As such, the prior founding experience is vital during both, the deal funding and deal monitoring phases. Consequently, VC teams with such capabilities are likely to be more agile in driving strategic decisions, particularly during unforeseen circumstances $[38,42,66]$. In this case, since the founding experience is in India, they possibly possess higher social capital as well, mainly in the form of formal and informal local networks. In the case of weak institutional frameworks (e.g., in China), informal understanding of the local milieu has been found to be an important guiding factor in VC investing $[44,80,81]$. The same rationale can be extended to India as well.

Furthermore, we find that homophily plays a vital role in determining syndication intensity. Among all known forms of homophily, the one based on race/ethnicity is likely to be the strongest. In our sample, an average of about 79 percent of IEs were of Indian origin. The homophily sentiments are likely to make it more amenable for the IEs to network with their counterparts from other VC firms (especially in informal settings), and thus facilitate syndication. Accordingly, we find that FVCFs with a relatively lower proportion of professionals of Indian origin $(<25 \%)$ were found to syndicate less intensely.

Along with non-tangible resources, syndication facilitates the pooling of tangible resources (i.e., funds) as well. Co-investing with other VCs enables the FVCFs to support much higher deal sizes [62]. Moreover, for VC firms with relatively smaller fund sizes, syndication is the primary tool for enabling portfolio diversification [15]. Our results support these earlier findings well, i.e., the FVCFs with relatively higher fund sizes exhibited a propensity to syndicate less intensely

Although we did not create specific variables to represent social capital in our models, they may be proxied by some of our model controls (viz., age and investment experience of the FVCF and the mode of foreign market entry). Local know-how (of socio-cultural contexts, institutions, policies, and frameworks) is an important resource for FVCFs [12,18]. Accordingly, better insight into local contexts is likely to reduce their syndication intensity. On the contrary, a superior understanding of the local milieu is also helpful in building strong local networks [80,82], thus facilitating the search for appropriate syndication partners. By this reasoning, FVCFs with a better understanding of the local conditions might possibly syndicate more intensely. Accordingly, in our regression results, we found that FVCFs with a relatively higher magnitude of historical investments tended to syndicate more intensely. Along similar lines, the FVCFs with greater numbers of years of experience were likely to syndicate more intensely, as well.

Interestingly, the relationship between the number of deals historically funded and the intensity of syndication was found to be curvilinear (inverted U-shaped). Thus, FVCFs with a relatively lower 
number of funded deals (fewer than 7) and those with a relatively high number of funded deals (greater than 28) were observed to syndicate less intensely when compared to VC firms that had funded deals within this range. This can be explained by the following: Fewer deals indicates lower exposure to the Indian conditions, resulting in limited local networks. This possibly makes it difficult for them to establish syndication alliances. In contrast, the FVCFs with a good depth of existing funding experience do not deem it essential to syndicate intensely, owing to the adequacy of their resulting social capital. A similar inverted U-shaped relationship between historical reputation of the FVCFs and their syndication propensity resulting from the opposing mechanisms of the need and opportunities for co-investment was observed in China, as well [83]. In the Chinese context, Huang et al. [12] showed that relatively younger FVCFs preferred to co-invest with domestic counterparts, owing to their having limited networks of their own. However, with experience, the need to co-invest with local partners declines significantly [12]. We need further research to explore whether this is indeed an explanation in India.

For a long time, geographical proximity between VC firms and investee ventures has been found to be vital for the reduction of VC investment-related risks [51,84]. In the VC investing world, where knowledge of high-quality deals is seldom public, physical proximity facilitates access to organizational networks [84]. It is with this purpose that the FVCFs establish physical offices in their investment destinations [85]. In the case of China, the establishment of physical offices has been found to decrease uncertainty and simplify monitoring [12,18]. Since the presence of an India office is likely to enhance the access to local knowledge and networks, it might potentially reduce the necessity to syndicate intensely. Accordingly, in our model results, we find that FVCFs with a physical office in India tended to syndicate with lower intensity.

In addition to the variables depicting human, social, and financial capital, we also checked for the effect of portfolio-focus-related variables on syndication intensity. For this, we considered two important variables as our controls: early stage focus and high-tech domain focus. Quite interestingly, we find that high exposure to early-stage deals in the VC firm portfolio lowers its syndication intensity. Although this finding might initially appear to be counter-intuitive, we can explain it as follows. It must be reiterated here that as a measure of 'early stage focus', we created an indicator variable (to identify the specific FVCFs with the proportion of early stage deals $>90$ per cent) and used it as a predictor in the model. This variable essentially captures the early stage specialization trait of the concerned FVCF. It is a well-known fact that 'domain specialization' itself is a valuable resource, lowering the reliance on syndication [86]. Furthermore, the learning curve benefits arising from a VC firm's specialized activity have been well-documented [87]. Naturally, VC firms that are highly specialized in specific domains are likely to exhibit a much lower incidence of syndication.

Furthermore, we find that FVCFs with a greater proportion of deals in high-tech domains tend to syndicate more intensely. This finding has been well-supported by literature. The information asymmetry and the ensuing uncertainty arising from the intangibility of assets warrants the pooling of incremental resources from the viewpoint of better deal screening and portfolio monitoring, consequently shielding VC firms from the ensuing risks [11,66,88]. Earlier research was focused on entrepreneurs'/TMTs' values, behavioral integration, and orientations, and their impact on the innovativeness and sustainability orientation the funded firms $[89,90]$. However, a missing aspect is the linkage between top management teams and risk management strategies in the finance (especially VC industry) [89].

\section{Conclusions}

In this exploratory paper, we have tried to assess the relative roles of tangible and non-tangible resources in impacting the intensity of syndication of FVCFs. While our results establish the syndication intensity as being impacted by both of these resource types, it also points out the significance of both 'need' and 'opportunity' in impacting syndication behavior. We show that owing to a superior understanding of cultural contexts and local circumstances, factors such as ethnicity, age, and the 
quantum of deals historically funded enhance the 'opportunities' to syndicate. In contrast, other attributes such as presence of prior founding experience and a greater size of financial and human resources reduces the 'need' to syndicate.

This study makes a few important contributions to the existing literature. To start with, we contribute to the literature on TMTs. While TMTs for other types of firms have been explored earlier, those of VCs have received only limited attention. By exploring factors such as ethnicity, we go beyond the conventionally explored factors such as education and professional backgrounds. To the best of our knowledge, this is the first study that explores the TMTs of VCs in the cross-border context.

Furthermore, we contribute to the literature on VC syndication. While previous studies have viewed syndication as a rather mechanical process that occurs in a vacuum, we explore the explicit link between human capital of the VCs and syndication and show how the latter is effected by the conscious efforts of the VC IEs from leveraging their social capital.

Finally, it extends the understanding of the operations of FVCFs in India - especially their syndication strategies. While similar studies have been carried out for China, this is the first study in the context of syndication for India. Moreover, while the focus of the Chinese studies was the choice of the co-investment partner, our study takes a different course by analyzing the 'intensity' of syndication.

This study has important managerial implications as well. To start with, for FVCFs it provides an insight into their most valuable resources and how the same can be leveraged to determine the most optimal syndication strategy. Furthermore, it provides a definite direction with respect to the specific skillsets that the FVCFs need to look out for in their IEs in their offices in emerging economies. In this context, it offers clear-cut guidelines about how specific factors such as local ethnicity of the team members and their native founding experience, could possibly compensate for the former's limited 'social capital'. Additionally, it provides FVCFs with vital advice regarding their entry strategies in emerging markets by recommending the establishment of physical offices in investment destinations, from the viewpoint of facilitating imminent co-investment relationships.

There are a few limitations of this study. The data used covers the period from 2005 to 2013. Although the VC industry in India has grown in leaps and bounds since then, the principal trends observed in the industry in terms of its industry focus or stage-focus have remained the same. Nevertheless, it might be a good idea to revise the study based on more recent data. Also, there could be many other possible extensions of this study. Although our sample virtually covers the entire population of FVCFs in India, owing to its still evolving nature, our study can be best classified as exploratory. While it is certainly important to understand the factors impacting the intensity of syndication, it would be further interesting to probe the profiles of the specific syndication partners. Particularly, it could be intriguing to analyze the circumstances that motivate the FVCFs to syndicate with Indian vis-a-vis other FVCFs. Another possible extension would be to analyze the impact of TMT composition on VC firm performance in the cross-border context. It might also be important to supplement this quantitative study with qualitative case-studies based on syndication experiences of some hand-picked FVCFs.

Author Contributions: K.J., the lead author of the paper, compiled the data and conceptualized the paper. D.C. worked on the literature review in addition to assisting K.J. on the methodology part. A.B. and K.S.M. provided conceptual input to enhance the quality of the literature review, the discussion of results and the implications of the study.

Funding: This research was self-funded and did not receive any external funding.

Acknowledgments: The initial version of this article was presented in Academy of International Business (AIB) 2018, which was held in Minneapolis, USA. The authors would like to thank the anonymous reviewers and juries/editors of both AIB conference and Sustainability journal for the constructive comments to enhance the quality of the paper. The authors also acknowledge and sincerely thank Prof. Sarika Pruthi, San Jose State University, for the valuable feedback at each stage of development of the paper. In addition, the authors place on record their gratitude to Prof. M H Bala Subrahmanya, Indian Institute of Science for his guidance.

Conflicts of Interest: The authors declare no conflict of interest. 


\section{References}

1. Hambrick, D.C.; Mason, P.A. Upper echelons: The organization as a reflection of its top managers. Acad. Manag. Rev. 1984, 9, 193-206. [CrossRef]

2. Carpenter, M.A. The implications of strategy and social context for the relationship between top management team heterogeneity and firm performance. Strat. Manag. J. 2002, 23, 275-284. [CrossRef]

3. Carpenter, M.A.; Geletkanycz, M.A.; Sanders, W.G. Upper echelons research revisited: Antecedents, elements, and consequences of top management team composition. J. Manag. 2004, 30, 749-778. [CrossRef]

4. Collins, C.J.; Clark, K.D. Strategic human resource practices, top management team social networks, and firm performance: The role of human resource practices in creating organizational competitive advantage. Acad. Manag. J. 2003, 46, 740-751.

5. Sulkowski, A.J.; Edwards, M.; Freeman, R.E. Shake your stakeholder: Firms leading engagement to cocreate sustainable value. Organ. Env. 2018, 31, 223-241. [CrossRef]

6. Manigart, S.; Wright, M.; Lockett, A.; Meuleman, M.; Landström, H.; Bruining, H.; Desbrieres, P.; Hommel, U. Why Do European Venture Capital Companies Syndicate? (April 2002, 11). ERIM Report Series Reference No. ERS-2002-98-ORG. 2002. Available online: https://ssrn.com/abstract=371048 (accessed on 10 September 2019).

7. Jungwirth, C.; Moog, P. Selection and support strategies in venture capital financing: High-tech or low-tech, hands-off or hands-on? Ventur. Cap. 2004, 6, 105-123. [CrossRef]

8. Gottschalg, O.; Gerasymenko, V. February. Antecedents and consequences of venture capital syndication. SSRN Atlanta Compet. Advant. Conf. Pap. 2008. [CrossRef]

9. Pruthi, S.; Wright, M.; Lockett, A. Do Foreign and Domestic Venture Capital Firms Differ in Their Monitoring of Investees? Asia Pac. J. Manag. 2003, 20, 175-204. [CrossRef]

10. Dai, N.; Jo, H.; Kassicieh, S. Cross-border venture capital investments in Asia: Selection and exit performance. J. Bus. Ventur. 2012, 27, 666-684. [CrossRef]

11. Joshi, K. Managing the risks from high-tech Investments in India: Differential strategies of foreign and domestic venture capital firms. J. Glob. Entrep. Res. 2018, 8, 21. [CrossRef]

12. Huang, X.; Kenney, M.; Patton, D. Responding to uncertainty: Syndication partner choice by foreign venture capital firms in China. Ventur. Cap. 2015, 17, 215-235. [CrossRef]

13. Bergemann, D.; Hege, U. Venture capital financing, moral hazard, and learning. J. Bank. Finance 1998, 22, 703-735. [CrossRef]

14. Lockett, A.; Wright, M. The syndication of private equity: Evidence from the UK. Ventur. Cap. 1999, 1, 303-324. [CrossRef]

15. Lockett, A.; Wright, M. The syndication of venture capital investments. Omega 2001, 29, 375-390. [CrossRef]

16. Makela, M.M.; Maula, M.V. Interorganizational Commitment in Syndicated Cross-Border Venture Capital Investments. Entrep. Theory Pr. 2006, 30, 273-298. [CrossRef]

17. Wright, M.; Pruthi, S.; Lockett, A. International venture capital research: From cross-country comparisons to crossing borders. Int. J. Manag. Rev. 2005, 7, 135-165. [CrossRef]

18. Meuleman, M.; Wright, M. Cross-border private equity syndication: Institutional context and learning. J. Bus. Ventur. 2011, 26, 35-48. [CrossRef]

19. Devigne, D.; Vanacker, T.; Manigart, S.; Paeleman, I. The role of domestic and cross-border venture capital investors in the growth of portfolio companies. Small Bus. Econ. 2013, 40, 553-573. [CrossRef]

20. Planning Commission. Creating a Vibrant Entrepreneurial Ecosystem for India; Report of the Committee on Angel Investment and Early Stage Venture Capital; Government of India/Planning Commission: New Delhi, India, 2012.

21. Bain and Company. India Private Equity Report. 2012. Available online: http://www.bain.com/publications/ (accessed on 10 September 2019).

22. Zarutskie, R. The role of top management team human capital in venture capital markets: Evidence from first-time funds. J. Bus. Ventur. 2010, 25, 155-172. [CrossRef]

23. Saxenian, A. Local and Global Networks of Immigrant Professionals in Silicon Valley; Public Policy Institute of California: San Francisco, CA, USA, 2002.

24. Zweig, D.; Chen, C. China's Brain Drain to the United States: The Views of Overseas Students and Scholars in the 1990s; Routledge: Abingdon, UK, 2013.

25. Huang, Y.; Khanna, T. Can India Overtake China? Foreign Policy 2003, 137, 74-81. [CrossRef] 
26. Bain and Company. India Private Equity Report. 2014. Available online: http://www.bain.com/publications/ (accessed on 10 September 2019).

27. Bain and Company. India Private Equity Report. 2011. Available online: http://www.bain.com/publications/ (accessed on 10 September 2019).

28. Bain and Company. India Private Equity Report. 2013. Available online: http://www.bain.com/publications/ (accessed on 10 September 2019).

29. Venture Intelligence. Database on Private Company Financials, Transactions \& Valuations for India. 2014. Available online: http://www.ventureintelligence.com (accessed on 10 September 2019).

30. World Bank. 2019. Available online: https://www.worldbank.org/content/dam/doingBusiness/media/AnnualReports/English/DB2019-report_web-version.pdf (accessed on 10 September 2019).

31. Transparency International Public Sector Corruption Index. 2014. Available online: http://www.transparency. org/cpi2014/regional_analysis (accessed on 10 September 2019).

32. Panda, S.; Dash, S.K. Friends and strangers: Leveraging the power of networks for new venture success. Dev. Learn. Organ. 2015, 29, 6-9. [CrossRef]

33. Sambharya, R.B. Research Notes and Communications: Foreign experience of top management teams and international diversification strategies of US multinational corporations. Strat. Manag. J. 1996, 17, 739-746. [CrossRef]

34. Tihanyi, L.; Ellstrand, A.E.; Daily, C.M.; Dalton, D.R. Composition of the top management team and firm international diversification. J. Manag. 2000, 26, 1157-1177. [CrossRef]

35. Carpenter, M.A.; Fredrickson, J.W. Top management teams, global strategic posture, and the moderating role of uncertainty. Acad. Manag. J. 2001, 44, 533-545.

36. Papadakis, V.M.; Barwise, P. How much do CEOs and top managers matter in strategic decision-making? Br. J. Manag. 2002, 13, 83-95. [CrossRef]

37. Kor, Y.Y. Experience-based top management team competence and sustained growth. Organ. Sci. 2003, 14, 707-719. [CrossRef]

38. MacMillan, I.C.; Narasimha, P.N. Research notes and communications: Characteristics distinguishing funded from unfunded business plans evaluated by venture capitalists. Strat. Manag. J. 1987, 8, 579-585. [CrossRef]

39. Franke, N.; Gruber, M.; Harhoff, D.; Henkel, J. What you are is what you like-Similarity biases in venture capitalists' evaluations of start-up teams. J. Bus. Ventur. 2006, 21, 802-826. [CrossRef]

40. Dimov, D.; Shepherd, D.A.; Sutcliffe, K.M. Requisite expertise, firm reputation, and status in venture capital investment allocation decisions. J. Bus. Ventur. 2007, 22, 481-502. [CrossRef]

41. Dimov, D.P.; Shepherd, D.A. Human capital theory and venture capital firms: Exploring "home runs" and "strike outs". J. Bus. Ventur. 2005, 20, 1-21. [CrossRef]

42. Patzelt, H.; zu Knyphausen-Aufseß, D.; Fischer, H.T. Upper echelons and portfolio strategies of venture capital firms. J. Bus. Ventur. 2009, 24, 558-572. [CrossRef]

43. Madhavan, R.; Iriyama, A. Understanding global flows of venture capital: Human networks as the "carrier wave" of globalization. J. Int. Bus. Stud. 2009, 40, 1241-1259. [CrossRef]

44. Bruton, G.D.; Ahlstrom, D. An institutional view of China's venture capital industry: Explaining the differences between China and the West. J. Bus. Ventur. 2003, 18, 233-259. [CrossRef]

45. Barney, J.; Wright, M.; Ketchen, D.J. The resource-based view of the firm: Ten years after 1991. J. Manag. 2001, 27, 625-641. [CrossRef]

46. Chandrashekar, D.; Bala Subrahmanya, M.H. Absorptive capacity, cluster linkages, and innovation: An evidence from Bengaluru high-tech manufacturing cluster. J. Manuf. Technol. Manag. 2018, 29, 121-148. [CrossRef]

47. Lerner, J. The Syndication of Venture Capital Investments. Financ. Manag. 1994, 23, 16-27. [CrossRef]

48. Cumming, D.; Fleming, G.; Suchard, J.-A. Venture capitalist value-added activities, fundraising and drawdowns. J. Bank. Finance 2005, 29, 295-331. [CrossRef]

49. Dimov, D.; Milanov, H. The interplay of need and opportunity in venture capital investment syndication. J. Bus. Ventur. 2010, 25, 331-348. [CrossRef]

50. Gorman, M.; Sahlman, W.A. What do venture capitalists do? J. Bus. Ventur. 1989, 4, 231-248. [CrossRef]

51. Sorenson, O.; Stuart, T.E. Syndication networks and the spatial distribution of venture capital investments1. Am. J. Soc. 2001, 106, 1546-1588. [CrossRef] 
52. Adler, P.S.; Kwon, S.W. Social capital: Prospects for a new concept. Acad. Manag. Rev. 2002, 27, 17-40. [CrossRef]

53. Hitt, M.A.; Duane, R. The essence of strategic leadership: Managing human and social capital. J. Leadersh. Organ. Stud. 2002, 9, 3-14. [CrossRef]

54. Zaheer, A.; Gulati, R.; Nohria, N. Strategic networks. Strat. Manag. J. 2000, 21, 203.

55. Nahapiet, J.; Ghoshal, S. Social capital, intellectual capital, and the organizational advantage. Acad. Manag. Rev. 1998, 23, 242-266. [CrossRef]

56. Joshi, K.; Bala Subrahmanya, M.H. Information Asymmetry Risks in Venture Capital (VC) Investments: Strategies of Transnational VC Firms in India. In Transnational Entrepreneurship; Springer: Singapore, 2019; pp. 117-142.

57. Liu, Y.; Maula, M. Local partnering in foreign ventures: Uncertainty, experiential learning, and syndication in cross-border venture capital investments. Acad. Manag. J. 2016, 59, 1407-1429. [CrossRef]

58. Davidsson, P.; Honig, B. The role of social and human capital among nascent entrepreneurs. J. Bus. Ventur. 2003, 18, 301-331. [CrossRef]

59. Bantel, K.A.; Jackson, S.E. Top management and innovations in banking: Does the composition of the top team make a difference? Strat. Manag. J. 1989, 10, 107-124. [CrossRef]

60. Amason, A.C.; Shrader, R.C.; Tompson, G.H. Newness and novelty: Relating top management team composition to new venture performance. J. Bus. Ventur. 2006, 21, 125-148. [CrossRef]

61. Zacharakis, A.L.; Shepherd, D.A. The nature of information and overconfidence on venture capitalists' decision making. J. Bus. Ventur. 2001, 16, 311-332. [CrossRef]

62. Jääskeläinen, M. Venture capital syndication: Synthesis and future directions. Int. J. Manag. Rev. 2012, 14, 444-463. [CrossRef]

63. Wright, M. Venture capital in China: A view from Europe. Asia Pac. J. Manag. 2007, 24, 269-281. [CrossRef]

64. Hopp, C.; Rieder, F. What drives venture capital syndication? Appl. Econ. 2011, 43, 3089-3102. [CrossRef]

65. McPherson, M.; Smith-Lovin, L.; Cook, J.M. Birds of a feather: Homophily in social networks. Annu. Rev. Soc. 2001, 27, 415-444. [CrossRef]

66. Timmons, J.A.; Sapienza, H.J. Venture capital: The decade ahead. State Art Entrep. 1992, 402, 437.

67. Burt, R.S. The contingent value of social capital. Adm. Sci. Q. 1997, 42, 339-365. [CrossRef]

68. Dossani, R.; Kenney, M. Creating an environment for venture capital in India. World Dev. 2002, 30, $227-253$. [CrossRef]

69. Scarlata, M.; Walske, J.; Zacharakis, A. Ingredients matter: How the human capital of philanthropic and traditional venture capital differs. J. Bus. Ethics 2017, 145, 623-635. [CrossRef]

70. Bertoni, F.; Colombo, M.G.; Quas, A. The role of governmental venture capital in the venture capital ecosystem: An organizational ecology perspective. Entrep. Theory Pract. 2019, 43, 611-628. [CrossRef]

71. Siepel, J.; Cowling, M.; Coad, A. Non-founder human capital and the long-run growth and survival of high-tech ventures. Technovation 2017, 59, 34-43. [CrossRef]

72. Sanders, W.G.; Carpenter, M.A. Internationalization and firm governance: The roles of CEO compensation, top team composition, and board structure. Acad. Manag. J. 1998, 41, 158-178.

73. Haleblian, J.; Finkelstein, S. Top management team size, CEO dominance, and firm performance: The moderating roles of environmental turbulence and discretion. Acad. Manag. J. 1993, 36, 844-863.

74. Amason, A.C.; Sapienza, H.J. The effects of top management team size and interaction norms on cognitive and affective conflict. J. Manag. 1997, 23, 495-516. [CrossRef]

75. Elango, B.; Fried, V.H.; Hisrich, R.D.; Polonchek, A. How venture capital firms differ. J. Bus. Ventur. 1995, 10, 157-179. [CrossRef]

76. Pullen, J.P. Emerging Tech: 9 International Start-Up Hubs to Watch. Entrepreneur. Business Daily USA. (7 May 2013). Available online: https://www.entrepreneur.com/slideshow/226477 (accessed on 10 September 2019).

77. Anjum, Z. Startup Capitals: Discovering the Global Hotspots of Innovation; Random House: Gurugram, India, 2014.

78. Garavaglia, S.; Sharma, A. A Smart Guide to Dummy Variables: Four Applications and a Macro. In Proceedings of the Northeast SAS Users Group Conference, Pittsburgh, PA, USA, 4-6 October 1998; p. 43.

79. Hair, J.F., Jr.; Anderson, R.E.; Tatham, R.L.; Black, W.C. Multivariate Data Analysis, 7th ed.; Macmillan: New York, NY, USA, 2015.

80. Anderson, H.D.; Chi, J.; Wang, Q.S. Political ties and VC exits: Evidence from China. China Econ. Rev. 2017, 44, 48-66. [CrossRef] 
81. Zhang, J. Venture capital in China. In China Innovation Nation; Oxford University Press: Oxford, UK, 2016; pp. 68-97.

82. Alexy, O.T.; Block, J.H.; Sandner, P.; Ter Wal, A.L. Social capital of venture capitalists and start-up funding. Small Bus. Econ. 2012, 39, 835-851. [CrossRef]

83. Gu, Q.; Lu, X. Unraveling the mechanisms of reputation and alliance formation: A study of venture capital syndication in China. Strat. Manag. J. 2014, 35, 739-750. [CrossRef]

84. Cumming, D.; Dai, N. Local bias in venture capital investments. J. Empir. Financ. 2010, 17, 362-380. [CrossRef]

85. Zhang, J. The spatial dynamics of globalizing venture capital in China. Environ. Plan. A 2011, 43, 1562-1580. [CrossRef]

86. De-Clercq, D.; Dimov, D. Explaining venture capital firms' syndication behaviour: A longitudinal study. Ventur. Cap. 2004, 6, 243-256. [CrossRef]

87. Norton, E.; Tenenbaum, B.H. Specialization versus diversification as a venture capital investment strategy. J. Bus. Ventur. 1993, 8, 431-442. [CrossRef]

88. Rosenstein, J.; Bruno, A.V.; Bygrave, W.D.; Taylor, N.T. The CEO, venture capitalists, and the board. J. Bus. Ventur. 1993, 8, 99-113. [CrossRef]

89. Jahanshahi, A.A.; Brem, A. Sustainability in SMEs: Top management teams behavioral integration as source of innovativeness. Sustainability 2017, 9, 1899. [CrossRef]

90. Jahanshahi, A.A.; Brem, A.; Bhattacharjee, A. Who Takes More Sustainability-Oriented Entrepreneurial Actions? The Role of Entrepreneurs' Values, Beliefs and Orientations. Sustainability 2017, 9, 1636. [CrossRef]

(C) 2019 by the authors. Licensee MDPI, Basel, Switzerland. This article is an open access article distributed under the terms and conditions of the Creative Commons Attribution (CC BY) license (http://creativecommons.org/licenses/by/4.0/). 